for $\mathrm{BaBi}_{10} \mathrm{~B}_{6} \mathrm{O}_{25} \mathrm{a}=6.434 \AA, \mathrm{b}=11.763 \AA, \mathrm{c}=29.998 \AA$, cell volume $\mathrm{V}=2270.34 \AA, \mathrm{Z}=8$.

[1] Barbier J., Penin N., Denoyer A., Cranswick L.M. Solid State Sciences, 2005, 7, 1055. [2] Egorysheva A.V., Kargin Yu.F Zh.Neorg. Khim. 2006, 7, 2078. [3] Egorysheva A.V., Skorikov V.M., Volodin V.D., Myslitskiy O.E. \& Kargin Yu.F. Zh.Neorg. Khim. 2006, 12, 2078.

\section{Keywords: $\mathrm{BaBi}_{2} \mathrm{~B}_{2} \mathrm{O}_{7}, \mathrm{BaBi}_{10} \mathrm{~B}_{6} \mathrm{O}_{25}, \mathrm{BaBi}_{8} \mathrm{~B}_{2} \mathrm{O}_{16}$}

\section{FA2-MS14-P18}

\section{Isomorphic (Mg, K) Substitution in Triple \\ Molybdate $\mathrm{K}_{3+x} \mathrm{Li}_{1-x} \mathbf{M g}_{4}\left(\mathrm{MoO}_{4}\right)_{6}$. Tatyana $\mathrm{Yu}$.}

$\underline{\text { Kardash }}^{\mathrm{a}}$, Zoya A. Solodovnikova ${ }^{\mathrm{b}}$, Sergey F. Solodovnikov ${ }^{\mathrm{b}}$, Evgeniya S. Zolotova ${ }^{\mathrm{b}}$. ${ }^{\text {Boreskov }}$ Institute of Catalysis, SB RAS, Novosibirsk, Russia. ${ }^{\mathrm{b}}$ Nikolaev Institute of Inorganic Chemistry, SB RAS, Novosibirsk, Russia. E-mail: kardash@catalysis.ru

Subsolidus phase relations in the ternary system $\mathrm{Li}_{2} \mathrm{MoO}_{4}-\mathrm{K}_{2} \mathrm{MoO}_{4}-\mathrm{MgMoO}_{4}$ were studied at $480-570^{\circ} \mathrm{C}$ using X-ray powder diffraction (Bruker D8, CuK $\alpha$ ), which revealed the existence of a new nonstoichiometric triple molybdate $\mathrm{K}_{3+x} \mathrm{Li}_{1-x} \mathrm{Mg}_{4}\left(\mathrm{MoO}_{4}\right)_{6}$ formed in the quasi binary join $\mathrm{K}_{2} \mathrm{Mg}_{2}\left(\mathrm{MoO}_{4}\right)_{3}-\mathrm{Li}_{2} \mathrm{Mg}_{2}\left(\mathrm{MoO}_{4}\right)_{3}$. The compound was found to be decomposed at $730^{\circ} \mathrm{C}$ into a solid mixture of $\beta-\mathrm{K}_{2} \mathrm{Mg}_{2}\left(\mathrm{MoO}_{4}\right)_{3}$ and $\mathrm{Li}_{2} \mathrm{Mg}_{2}\left(\mathrm{MoO}_{4}\right)_{3}$. The homogeneity range $0 \leq x \leq 0.25$ was found from the dependences of the trigonal unit cell parameters on the composition for powder samples quenched in air from $500^{\circ} \mathrm{C}$ (see Table). Crystals of the compound were obtained by spontaneous crystallization of the molten ceramic mixture $\mathrm{Li}_{2} \mathrm{MoO}_{4}+2 \mathrm{~K}_{2} \mathrm{MoO}_{4}+2 \mathrm{MgMoO}_{4}+$ $2 \mathrm{~K}_{2} \mathrm{Mo}_{2} \mathrm{O}_{7}$ cooled from $610^{\circ} \mathrm{C}$. The crystal structure of $\mathrm{K}_{3.11} \mathrm{Li}_{0.89} \mathrm{Mg}_{4}\left(\mathrm{MoO}_{4}\right)_{6}$ (Bruker X8 Apex, $a=14.3541(2) \AA$, $c=19.7338(4) \AA$, sp. gr. $R \overline{3} c, \mathrm{Z}=6, R=0.0191)$ is isotypical to that of the sodium-ion conductor II- $\mathrm{Na}_{3} \mathrm{Fe}_{2}\left(\mathrm{AsO}_{4}\right)_{3}=$ $\left(\mathrm{Na}_{5} \square\right)^{\mathrm{IX}} \mathrm{Na}^{\mathrm{VI}} \mathrm{Fe}^{\mathrm{VI}} \mathrm{Fe}^{\mathrm{VI}}{ }_{3}\left(\mathrm{AsO}_{4}\right)_{6}$ [1], and has the following cationic distribution: $\left(\mathrm{K}_{0.5} \square_{0.5}\right)_{6}\left(\mathrm{Mg}_{0.89} \mathrm{~K}_{0.11}\right)\left(\mathrm{Li}_{0.89} \mathrm{Mg}_{0.11}\right)$ $\mathrm{Mg}_{3}\left(\mathrm{MoO}_{4}\right)_{6}$. The main interatomic distances $(\AA)$ are: Mo-O $1.753(2)-1.768(2), \quad \mathrm{K}-\mathrm{O} \quad 2.771(2)-3.512(2), \quad(\mathrm{Mg}, \quad \mathrm{K})-\mathrm{O}$ $2.152(2) \times 6, \quad(\mathrm{Li}, \quad \mathrm{Mg})-\mathrm{O} \quad 2.075(2) \times 6, \quad \mathrm{Mg}-\mathrm{O}$ 2.034(2)-2.134(2). The structure comprises 3D framework built of $\mathrm{MoO}_{4}$ tetrahedra and oxygen octahedra around three Mg-containing positions where each $(\mathrm{Li}, \mathrm{Mg}) \mathrm{O}_{6}$ octahedron shares edges with three $\mathrm{MgO}_{6}$ octahedra to form discrete octahedral tetra-clusters while the $(\mathrm{Mg}, \mathrm{K}) \mathrm{O}_{6}$ octahedra are isolated. Large cavities of the framework are half occupied by $\mathrm{K}^{+}$ions. The unexpected feature of the structure is an isomorphic $(\mathrm{Mg}, \mathrm{K})$ substitution revealed for the first time. The analogous $(\mathrm{Mn}, \mathrm{K})$ and $(\mathrm{Co}, \mathrm{K})$ substitutions were early found in the isostructural compounds $\mathrm{K}_{3.07} \mathrm{Li}_{0.93} \mathrm{Mn}_{4}\left(\mathrm{MoO}_{4}\right)_{6}$ and $\mathrm{K}_{3.30} \mathrm{Li}_{0.70} \mathrm{Co}_{4}\left(\mathrm{MoO}_{4}\right)_{6}$ [2]. The open framework structures, the presence of defects in the $\left(\mathrm{K}_{0.5} \square_{0.5}\right)$ position and a structural relation of these three triple molybdates with the solid electrolyte II- $\mathrm{Na}_{3} \mathrm{Fe}_{2}\left(\mathrm{AsO}_{4}\right)_{3}$ make us to suggest ionic exchange properties and an elevated ionic conductivity for the compounds considered.

\begin{tabular}{|l|l|l|}
\hline Composition of sample & $a, \AA$ & $c, \AA$ \\
\hline $\mathrm{K}_{2.9} \mathrm{Li}_{1.1} \mathrm{Mg}_{4}\left(\mathrm{MoO}_{4}\right)_{6}{ }^{*}$ & $14.350(1)$ & $19.703(2)$ \\
\hline $\mathrm{K}_{3.0} \mathrm{Li}_{1.0} \mathrm{Mg}_{4}\left(\mathrm{MoO}_{4}\right)_{6}$ & $14.350(1)$ & $19.703(2)$ \\
\hline $\mathrm{K}_{3.1} \mathrm{Li}_{0.9} \mathrm{Mg}_{4}\left(\mathrm{MoO}_{4}\right)_{6}$ & $14.353(1)$ & $19.704(2)$ \\
\hline $\mathrm{K}_{3.2} \mathrm{Li}_{0.8} \mathrm{Mg}_{4}\left(\mathrm{MoO}_{4}\right)_{6}$ & $14.358(1)$ & $19.706(2)$ \\
\hline $\mathrm{K}_{3.3} \mathrm{Li}_{0.7} \mathrm{Mg}_{4}\left(\mathrm{MoO}_{4}\right)_{6} * *$ & $14.360(1)$ & $19.709(2)$ \\
\hline
\end{tabular}

$* \mathrm{Li}_{2} \mathrm{Mg}_{2}\left(\mathrm{MoO}_{4}\right)_{3}$ impurity. $\quad * * \beta-\mathrm{K}_{2} \mathrm{Mg}_{2}\left(\mathrm{MoO}_{4}\right)_{3}$ impurity.

[1] D’Yvoire, F.; Bretey, E.; Collin G. Solid State Ionics, 1988, 28-30 1259. [2] Solodovnikov, S.F.; Khaikina, E.G.; Solodovnikova, Z.A.; Kadyrova, Yu.M.; Khal'baeva, K.M.; Zolotova, E.S. Doclady Chemistry, 2007, 416, Part 1, 207.

Keywords: triple molybdate, nonstoichiometry, structure

\section{FA2-MS14-P19}

Nanostructured Random Type $\mathrm{MgFe}_{2} \mathrm{O}_{4}$ Spinel

Prepared by Soft Mechanochemical Route. A.

Kremenovic $^{\mathrm{a}, \mathrm{b}}$, B. Antic ${ }^{\mathrm{b}}$, N. Jovic ${ }^{\mathrm{b}}$, M. Vucinic-Vasic ${ }^{\mathrm{c}}$.

${ }^{a}$ University of Belgrade, Belgrade, Serbia. ${ }^{b}$ The

"Vinča” Institute, Belgrade, Serbia. ${ }^{~}$ University of Novi

Sad, Novi Sad, Serbia.

E-mail: akremen@EUnet.rs

Results of structural, spectroscopic and magnetic investigations of $\mathrm{MgFe}_{2} \mathrm{O}_{4}$ nanoparticles prepared by soft mechanochemical synthesis will be reported. $\mathrm{MgFe}_{2} \mathrm{O}_{4}$ nanoparticles crystallize in $\mathrm{Fd} \overline{3} \mathrm{~m}$ space group with mixed cation distribution and reduced percentage of $\mathrm{Fe}^{3+}$ at tetrahedral (8a) sites. Discrepancy in the cation distribution compared to that in the bulk Mg-ferrite is one of the highest known. X-ray line broadening analysis reveals crystallite size and strain anisotropy. The average apparent size is $10(1) \mathrm{nm}$ and the average maximum strain is $27(2) \times 10^{-4}$. The projection of three-dimensional bodies representing "average apparent crystallite size" and "apparent maximum strain" on crystallographic (001) plane are given in Figure 1.
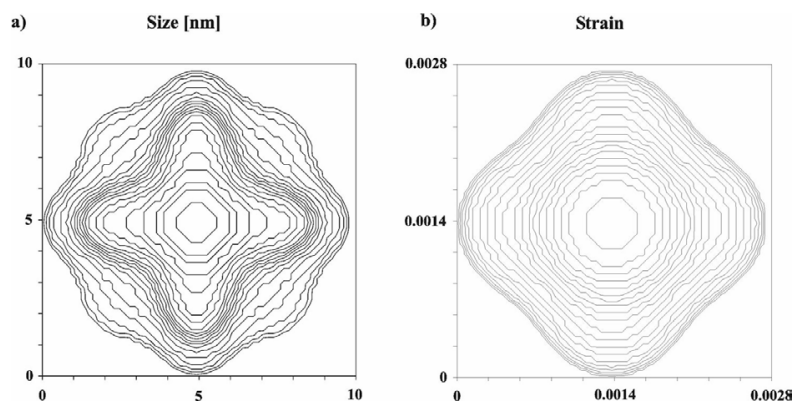

Figure 1. The projection of three-dimensional bodies representing (a) average apparent size and (b) maximum strain in crystallographic plane (001).

The saturation magnetization, $M_{\text {sat }}=62 \mathrm{emu} / \mathrm{g}$ measured at 5 $\mathrm{K}$ is twice higher than that found in the bulk counterparts. Such high value of $M_{\text {sat }}$ is attributed to the low value of cation inversion parameter $(\delta=0.69)$, to the core/shell structure of the nanoparticles and to the surface/volume ratio. Mössbauer spectrum collected at room temperature reveals ferrimagnetic ordering between $\mathrm{Fe}^{3+}$ ions in $8 a$ and $16 d$ sites, while zerofield-cooled (ZFC) and field-cooled (FC) $\mathrm{M}(\mathrm{T})$ measurements were shown SPM state above $350 \mathrm{~K}$.

Keywords: nanocrystals, microstructure analysis, magnetism 